\title{
Atypiske mykobakterier og lady Windermere
}

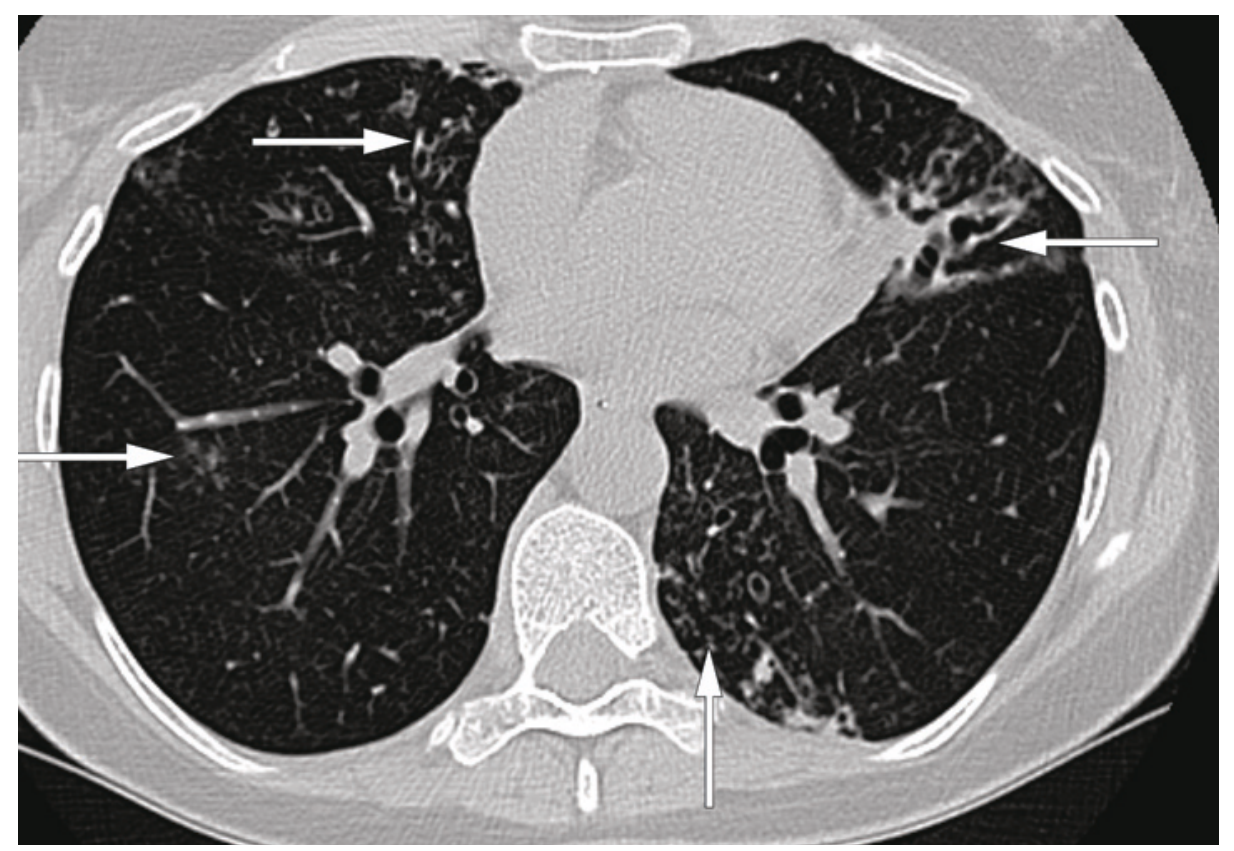

En tidligere frisk kvinne i 40-årene hadde hatt flere episoder med hemoptyse. Utredning med røntgen thorax og CT thorax ved et privat institutt hadde vist diffust avgrensede sentrilobulære noduli, dels omgitt av løst mettede, alveolære fortetninger (mattglassforandringer) basalt $\mathrm{i}$ begge overlapper og en ektatisk bronkialgren basalt $i$ venstre overlapp. Dessuten forelå det en liten kavitet sentralt i høyre overlapp.

Hemoptysen tiltok og kvinnen ble etter hvert innlagt i lokalsykehus for utredning. Bronkoskopi ved innleggelsen viste et stort koagel i midtlappsostiet og blodrester i alle lungeavsnitt. På CT-undersøkelse dagen etter innkomst var det kommet til mattglassfortetninger, forenlig med diffus alveolær blødning.

Det ble utført bakteriologisk undersøkelse og direkte mikroskopi av sputum. Dyrkning viste primært normalflora, men seks uker etter innleggelsen kom det positivt dyrkningssvar for Mycobacterium avium-kompleks (MAC). Pasienten fikk trippelbehandling (klaritromycin, etambutol og rifampicin) $i$ to år, men den ble avsluttet grunnet fortsatt positive dyrkninger og progredierende radiologiske funn. I forløpet frem til seneste CTkontroll syv år etter første innleggelse er det kommet til gradvis økende, multifokale bronkiektasier samt økt kavitetsdanning i høyre overlapp (bildet). Hun følges fortsatt poliklinisk - det kliniske bildet er relativt stabilt og hun har tilfredsstillende lungefunksjon.

MAC-komplekset består av Mycobacterium avium og Mycobacterium intracellulare, atypiske mykobaterier som forekommer i jord og vann. Hos mennesker er de de hyppigst forekommende i gruppen ikke-tuberkuløse mykobaterier (NTM) (1). Infeksjonen rammer oftest immunsupprimerte, men bakteriene kan også gi infeksjon hos tidligere friske mennesker uten immundefekter (2). Det er blitt spekulert på om undertrykt hosterefleks medvirker til sykdomsutviklingen, og fenomenet har fått navnet lady Windermeres syndrom etter Oscar Wildes skuespill Lady Windermere's fan. Datidens sosiale kodeks tilsa at kvinner ikke skulle hoste eller harke (3).

Typiske radiologiske funn ved MACinfeksjoner er multiple nodulære fortetninger, multifokale bronkiektasier og kaviteter (4). Tidlig diagnostikk og rask oppstart av behandling kan være av betydning for graden av irreversibel luftveisskade. CT thorax er følsom for tidlige parenkymforandringer, og et nært samarbeid mellom infeksjonsmedisiner og radiolog kan bidra til raskere diagnose.

Pasienten har gitt samtykke til at artikkelen blir publisert.

\section{Benedicte Falkenberg-Jensen}

b-falkenberg@hotmail.com

Klinikk for radiologi og nukleærmedisin

Trond Mogens Aaløkken

Radiologisk avdeling

\section{Børre Fevang}

Seksjon for klinisk immunologi

og infeksjonssykdommer

Oslo universitetssykehus, Rikshospitalet
Benedicte Falkenberg-Jensen (f. 1976) er spesialist i radiologi og overlege ved seksjon for thorax-, kar-og øre-nese-halsradiologi. Forfatter har fylt ut ICMJE-skjemaet og oppgir ingen interessekonflikter.

Trond Mogens Aaløkken (f. 1957) er ph.d. og enhetsoverlege.

Forfatter har fylt ut ICMJE-skjemaet og oppgir ingen interessekonflikter.

Børre Fevang (f. 1969) er spesialist i indremedi sin og infeksjonssykdommer og overlege. Han har særlig interesse for primær immunsvikt. Forfatter har fylt ut ICMJE-skjemaet og oppgir ingen interessekonflikter.

Litteratur

1. Folkehelseinstituttet. Tuberkuloseveilederen 2015 www.fhi.no/publikasjoner-og-haandboker/ tuberkuloseveilederen (25.5.2016)

2. Prince DS, Peterson DD, Steiner RM et al. Infection with Mycobacterium avium complex in patients without predisposing conditions. N Engl J Med 1989; 321: 863-8.

3. Reich JM, Johnson RE. Mycobacterium avium complex pulmonary disease presenting as an isolated lingular or middle lobe pattern. The Lady Windermere syndrome Chest 1992: 101: 1605-9.

4. Medical Section of the American Lung Association. Diagnosis and treatment of disease caused by nontuberculous mycobacteria. This official statement of the American Thoracic Society was approved by the Board of Directors, March 1997. Am J Respir Crit Care Med 1997; 156: S1-25. 